\title{
Cross-craft interactions between metal and glass working: slag additions to early Anglo-Saxon red glass
}

\author{
James R. N. Peake ${ }^{* a}$, Ian C. Freestone ${ }^{\mathrm{b}}$ \\ ${ }^{a}$ Department of Archaeology and Conservation, Cardiff University, Humanities Building, Colum \\ Drive, Cardiff, CF10 3EU, UK. \\ ${ }^{\mathrm{b}}$ Institute of Archaeology, University College London, 31-34 Gordon Square, London, WC1H 0PY, \\ UK.
}

\begin{abstract}
Opaque red glass has been extensively studied over the years, but its compositional complexity and variability means that the way in which it was manufactured is still not fully understood. Previous studies have suggested the use of metallurgical by-products in its manufacture, but until now the evidence has been limited. SEM-EDS analysis of glass beads from the early Anglo-Saxon cemetery complex at Eriswell, southeast England, has provided further insights into the production and technology of opaque red glass, which could only have been possible through invasive sampling. The matrix of the red glasses contains angular particles of slag, the main phases of which typically correspond to either fayalite $\left(\mathrm{Fe}_{2} \mathrm{SiO}_{4}\right)$ or kirschsteinite $\left(\mathrm{CaFeSiO}_{4}\right)$, orthosilicate (olivine-type) minerals characteristic of some copper- and iron-smelting slags. This material appears to have been added in part as a reducing agent, to promote the precipitation of sub-micrometer particles of the colorant phase, copper metal. Its use represents a sophisticated, if empirical, understanding of materials and can only have resulted through deliberate experimentation with metallurgical by-products by early glass workers. Slag also seems to have been added as a source of iron to colour 'black' glass. The compositions of the opaque red glasses appear to be strongly paralleled by Merovingian beads from northern Europe and Anglo-Saxon beads from elsewhere in England, suggesting that this technology is likely to have been quite widespread.
\end{abstract}

Keywords: red glass, black glass, beads, Anglo-Saxon, copper, slag, kirschsteinite, fayalite, nepheline, lead-tin yellow.

\section{INTRODUCTION}

Glass production shares with metallurgy a use of high temperatures along with a suite of relatively uncommon elements as colourants including antimony, copper, lead and tin. These common features have frequently led to speculation that the development of glass technologies was closely related to the metal production industries, from the origins of glass in the Late Bronze Age, ${ }^{1}$ through to later opacification practices using antimony or tin. ${ }^{2-5}$ While some of these ideas have proved controversial, ${ }^{6}$ others are more widely accepted. For example, the use of copper alloy scale in the colouration of pale blue or turquoise glass is generally inferred due to the association of elements such as tin and zinc with the copper colourant. ${ }^{7,8}$ However, this remains virtually the only unambiguous example of the use of a metallurgical by-product in glass technology, and can hardly be used to justify an interaction between the two industries, as copper alloy scrap would have been widespread in glass making societies and is unlikely to have been procured directly from metal workers.

The present paper reports direct evidence of the systematic use of a primary metallurgical by-product in early glass production. Its use represents a sophisticated, if empirical, understanding of materials which can only have resulted through deliberate experimentation with metallurgical by-products by these craftsmen. Our examples concern a large corpus of opaque red glass beads from an early Anglo-Saxon ( $5^{\text {th }}$ to $7^{\text {th }}$ century AD) cemetery in southeast England.

Opaque red glass has attracted considerable interest from glass researchers, on account of its compositional complexity and because the formation of colour requires a reducing environment in the glass. ${ }^{9-12}$ Furthermore, it appears to have performed an important decorative and symbolic role when used as enamel or inlay in high quality Celtic metalwork. ${ }^{13,14}$ It was also widely used in the form of tesserae in mosaics, and in a range of coloured glass vessels. Two broad categories

*peakejr@cardiff.ac.uk

Integrated Approaches to the Study of Historical Glass - IAS12, edited by Wendy Meulebroeck,

Karin Nys, Dirk Vanclooster, Hugo Thienpont, Proc. of SPIE Vol. 8422, 842204

(C) 2012 SPIE · CCC code: 0277-786X/12/\$18 · doi: 10.1117/12.973765

Proc. of SPIE Vol. $8422842204-1$ 
of early opaque red glass have been identified: a high lead - high copper type with around $20 \%$ or more $\mathrm{PbO}$ and $5-12 \%$ $\mathrm{CuO}$, and a low lead - low copper variety with just a few percent $\mathrm{CuO}$ and up to $15 \% \mathrm{PbO} .^{11,14-16}$ While not all examples of red glass can be categorised in this way, the great majority of analysed glasses fall into one or the other category. The colourant particles in the low-copper glasses are frequently below the resolution of routine scanning electron microscopy. However, direct observation using transmission electron microscopy (TEM) with electron diffraction reveals that the low-copper reds are typically coloured by minute nanoparticles of metallic copper, while the highcopper, high-lead glasses are coloured by cuprite, $\mathrm{Cu}_{2} \mathrm{O},{ }^{9,17}$ While the production methods of these glasses are not fully understood, the requirement of reducing conditions, whether through the imposition of a reducing furnace atmosphere, the addition of an internal reductant, or both, is generally agreed. ${ }^{11,18}$ Stapleton et al. ${ }^{14}$ have suggested that the red enamel on early medieval metalwork may represent the reuse of a raffination slag, resulting from the recovery of silver from recycled metalwork, while Freestone et al. ${ }^{19}$ have suggested that a range of opaque red glass may have been coloured directly by the addition of a copper-bearing metallurgical by-product, but the evidence is largely circumstantial.

\section{MATERIALS AND METHODS}

As part of the post-excavation work associated with the recent excavation of the Anglo-Saxon cemetery complex at Eriswell, Suffolk, a comprehensive analytical programme is underway on the glass beads from the site. Most of these beads, of which over 1000 are glass, were excavated from the female graves and have been examined and classified by Birte Brugmann. The majority have been tentatively ascribed to different chronological phases, corresponding to Brugmann's published typo-chronological groupings for Anglo-Saxon glass beads, ${ }^{20}$ dating to between 450 and 650 AD. They consist of a wide range of monochrome and polychrome types, the majority of which are either cylindrical or globular. Over 90 opaque red glasses from different beads have been analysed at present, amongst a large number of other translucent and opaque colours which it is not within the scope of this paper to discuss. Most of the samples under discussion were from the main body of beads, but approximately a quarter represent applied decoration.

Samples of approximately 1-2mm in size were taken from each bead, mounted in resin, polished flat and vacuum-coated with a thin layer of carbon. A scanning electron microscope (CamScan Maxim) equipped with an energy-dispersive xray analyser (SEM-EDS) was used to analyse for major and minor elements. Analyses were obtained using an Oxford Instruments INCA energy-dispersive x-ray spectrometer calibrated against pure elements, minerals and oxides. Operating conditions were a $20 \mathrm{kV}$ accelerating potential with a beam current adjusted to yield 4000 counts per second on metallic cobalt, for a counting live time of 100 seconds. The analyses, which totalled between $98 \%$ and $102 \%$, were normalised to $100 \%$ to improve precision and comparability. Based upon comparisons with Corning glass standards A and $\mathrm{B},{ }^{21}$ relative analytical accuracy and precision are believed to be better than $\pm 2 \%$ for silica and $\pm 5 \%$ for other elements present in concentrations greater than $10 \%$, but greater for elements present in lower concentrations. Detection limits were $0.1 \%$ for most of the components analysed, but up to $0.3 \%$ for lead, tin and copper. Precision is significantly reduced as the detection limits are approached. Three area analyses were obtained from each glass colour and an average taken. Due to the heterogeneity of the opaque red glass samples, slag particles were avoided during the acquisition of spectra. Individual phases of the slag inclusions present were determined by spot analysis. Area analysis was also undertaken to gauge the bulk composition of a number of the slag particles, where they were large enough to permit this.

\section{RESULTS}

Oxide compositions of a selection of the glasses analysed are presented in table 1, bulk analyses of slag inclusions in table 2, spot analyses of the individual phases within these in table 3, and spot analyses of nepheline inclusions in table 4 .

The glasses are of a soda-lime-silica composition, with low levels of both potash and magnesia (typically less than $1.5 \%$ each of $\mathrm{K}_{2} \mathrm{O}$ and $\mathrm{MgO}$ ), to which varying amounts of copper and lead were added. This glass type was made using a relatively pure alkali source, and is typical of glasses of the Roman, early medieval and Byzantine periods made using mineral natron from Egypt. ${ }^{22}$ Although the samples analysed are very heterogeneous, their microstructures are broadly similar. Most contain angular particles of slag, clearly visible in the SEM (figs. 1-5). The few samples in which slag was not observed have compositions comparable to those which do contain it (most notably their high iron contents), suggesting that slag was added, but dissolved or was not observed due to the small size of the samples. 
Table 1. EDS area analyses of selected opaque red Anglo-Saxon glass beads and a 'black' glass bead from Eriswell.

\begin{tabular}{|c|c|c|c|c|c|c|c|c|c|c|c|c|c|c|c|c|c|}
\hline \multirow[t]{2}{*}{ Sample } & \multicolumn{17}{|c|}{ Oxide $(w t \%)^{\mathrm{a}}$} \\
\hline & $\mathrm{Na}_{2} \mathrm{O}$ & MgO & $\mathbf{A l}_{2} \mathbf{O}_{3}$ & $\mathrm{SiO}_{2}$ & $\mathrm{P}_{2} \mathrm{O}_{5}$ & $\mathrm{SO}_{3}$ & $\mathrm{Cl}$ & $\mathrm{K}_{2} \mathrm{O}$ & $\mathrm{CaO}$ & $\mathrm{TiO}_{2}$ & MnO & $\mathrm{Fe}_{2} \mathrm{O}_{3}$ & $\mathrm{CuO}$ & $\mathrm{ZnO}$ & $\mathrm{SnO}_{2}$ & $\mathrm{BaO}$ & PbO \\
\hline \multicolumn{18}{|c|}{ Opaque red glass } \\
\hline ERL046:G03:1271 & 12.6 & 0.6 & 2.6 & 55.3 & 0.2 & 0.3 & 0.9 & 0.6 & 5.6 & 0.1 & 0.4 & 4.4 & 1.9 & b.d. & 0.1 & b.d. & 14.2 \\
\hline ERL046:G25:1691 & 11.7 & 0.5 & 2.6 & 51.7 & 0.3 & 0.3 & 0.7 & 0.7 & 4.9 & 0.1 & 0.5 & 3.3 & 4.2 & 0.1 & 0.8 & b.d. & 17.5 \\
\hline ERL046:G38:1046 & 14.0 & 0.6 & 2.5 & 57.9 & 0.2 & 0.4 & 0.8 & 0.9 & 5.8 & 0.1 & 0.5 & 2.4 & 2.4 & b.d. & b.d. & b.d. & 11.1 \\
\hline ERL046:G43:1721 & 11.8 & 0.6 & 2.4 & 50.8 & 0.1 & 0.5 & 0.8 & 0.9 & 4.7 & 0.1 & 0.5 & 3.6 & 1.1 & b.d. & 0.9 & b.d. & 21.4 \\
\hline ERL046:G43:1726 & 12.7 & 0.6 & 2.4 & 53.7 & 0.2 & 0.5 & 0.7 & 0.7 & 5.1 & 0.2 & 0.6 & 3.9 & 3.6 & b.d. & 0.5 & b.d. & 14.7 \\
\hline ERL104:G107:1127 & 13.6 & 0.6 & 2.7 & 63.9 & 0.2 & 0.1 & 0.9 & 0.6 & 7.7 & 0.1 & b.d. & 3.8 & 2.6 & 0.7 & b.d. & b.d. & 2.1 \\
\hline ERL104:G107:1141 & 12.9 & 1.5 & 2.1 & 51.7 & 0.5 & 0.4 & 0.5 & 1.4 & 7.4 & 0.2 & 1.5 & 6.1 & 1.9 & 0.5 & 1.6 & b.d. & 9.9 \\
\hline ERL104:G112:1025/1 & 16.0 & 1.1 & 2.6 & 61.7 & 0.2 & 0.3 & 0.7 & 0.9 & 6.9 & 0.1 & 1.6 & 5.0 & 1.3 & b.d. & b.d. & 0.1 & 0.9 \\
\hline ERL104:G148:2739 & 12.0 & 0.4 & 2.6 & 54.4 & 0.2 & 0.4 & 0.8 & 0.9 & 5.1 & 0.1 & 0.3 & 4.8 & 2.8 & b.d. & 0.1 & b.d. & 14.7 \\
\hline ERL104:G148:2743 & 13.3 & 0.5 & 2.4 & 51.4 & 0.1 & 0.4 & 0.8 & 0.7 & 5.2 & 0.1 & 0.7 & 4.0 & 1.9 & 0.1 & 1.5 & b.d. & 16.7 \\
\hline ERL104:G242:2145 & 14.0 & 0.8 & 2.6 & 55.8 & 0.3 & 0.2 & 0.8 & 0.7 & 4.9 & 0.3 & 1.2 & 5.8 & 2.5 & b.d. & 0.3 & b.d. & 9.6 \\
\hline ERL104:G242:2158 & 14.8 & 0.7 & 2.3 & 56.0 & 0.2 & 0.3 & 0.9 & 0.8 & 5.3 & 0.2 & 0.9 & 5.0 & 2.2 & b.d. & 0.5 & b.d. & 9.9 \\
\hline ERL104:G242:2203 & 13.0 & 0.7 & 2.0 & 47.3 & 0.2 & 0.4 & 0.7 & 0.6 & 4.9 & 0.2 & 1.0 & 4.7 & 1.2 & b.d. & 2.0 & b.d. & 21.4 \\
\hline ERL104:G242:2207 & 14.2 & 0.7 & 2.7 & 58.1 & 0.3 & 0.3 & 0.9 & 0.9 & 5.5 & 0.3 & 0.9 & 5.9 & 2.3 & b.d. & 0.3 & b.d. & 6.7 \\
\hline ERL104:G242:2282 & 12.5 & 0.7 & 2.1 & 47.5 & 0.3 & 0.4 & 0.8 & 0.6 & 4.7 & 0.3 & 1.1 & 4.6 & 1.3 & b.d. & 2.2 & b.d. & 20.8 \\
\hline ERL104:G262:1291 & 17.2 & 1.4 & 3.4 & 60.2 & 0.2 & 0.5 & 0.9 & 1.0 & 6.1 & 0.2 & 0.6 & 4.3 & 1.2 & 0.2 & 0.4 & 0.1 & 1.8 \\
\hline ERL104:G263:1406 & 13.6 & 0.6 & 2.4 & 56.5 & 0.2 & 0.3 & 0.9 & 0.7 & 5.4 & 0.1 & 0.5 & 2.7 & 2.5 & b.d. & 0.2 & b.d. & 13.2 \\
\hline ERL104:G268:3257 & 13.9 & 0.6 & 2.5 & 57.3 & 0.2 & 0.4 & 0.8 & 0.9 & 5.6 & 0.1 & 0.5 & 4.2 & 2.6 & b.d. & 0.7 & b.d. & 9.3 \\
\hline ERL104:G268:3258 & 11.5 & 0.7 & 2.6 & 49.3 & 0.2 & 0.3 & 0.7 & 0.7 & 4.7 & 0.2 & 1.1 & 3.8 & 1.2 & 0.2 & b.d. & 0.2 & 22.5 \\
\hline ERL104:G268:3260 & 15.2 & 0.8 & 2.6 & 54.8 & 0.2 & 0.3 & 0.9 & 0.8 & 4.9 & 0.3 & 1.7 & 5.1 & 0.9 & 0.1 & 0.8 & 0.5 & 10.4 \\
\hline ERL104:G281:1795 & 13.9 & 0.6 & 2.6 & 61.1 & 0.2 & 0.2 & 0.8 & 0.6 & 6.7 & 0.1 & 0.1 & 5.8 & 2.9 & 0.8 & b.d. & b.d. & 3.3 \\
\hline ERL104:G305:1820 & 13.3 & 0.5 & 2.5 & 55.5 & 0.2 & 0.4 & 0.8 & 0.7 & 5.4 & 0.1 & 0.5 & 4.7 & 2.0 & b.d. & 0.7 & b.d. & 12.5 \\
\hline ERL104:G315:2345 & 10.9 & 0.5 & 2.3 & 45.7 & 0.1 & 0.3 & 0.7 & 0.5 & 4.0 & 0.1 & 0.4 & 3.1 & 1.7 & 0.2 & 0.4 & b.d. & 29.5 \\
\hline ERL104:G353:3066 & 16.7 & 1.1 & 2.2 & 60.4 & 0.2 & 0.4 & 0.8 & 0.8 & 6.3 & 0.3 & b.d. & 3.4 & 2.8 & 1.1 & b.d. & b.d. & 3.1 \\
\hline ERL104:G353:3079 & 16.1 & 0.9 & 1.7 & 57.1 & 0.1 & 0.5 & 0.8 & 0.8 & 4.8 & 0.2 & 0.2 & 5.0 & 3.3 & 0.7 & 1.7 & b.d. & 6.0 \\
\hline ERL104:G362:1961 & 14.8 & 0.7 & 2.4 & 54.6 & 0.2 & 0.5 & 0.9 & 0.7 & 5.2 & 0.2 & 1.1 & 5.1 & 1.2 & 0.2 & 0.6 & 0.1 & 11.4 \\
\hline \multicolumn{18}{|c|}{ 'Black' glass } \\
\hline ERL104:G242:2273/16 & 11.8 & 0.7 & 2.1 & 44.2 & 0.3 & 0.3 & 0.8 & 0.6 & 4.1 & 0.2 & 1.1 & 8.0 & b.d. & b.d. & 1.6 & 0.1 & 24.0 \\
\hline
\end{tabular}

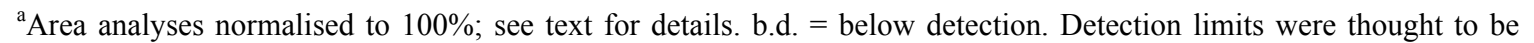
about $0.1 \%$ for most elements, although this is marginally higher for lead, tin and copper at about $0.25-0.3 \%$. The oxides of cobalt $(\mathrm{CoO})$ nickel $(\mathrm{NiO})$, arsenic $\left(\mathrm{As}_{2} \mathrm{O}_{3}\right)$ and antimony $\left(\mathrm{Sb}_{2} \mathrm{O}_{5}\right)$ were sought but not detected.

The glasses contain $0.9-4.2 \%$ copper, expressed as $\mathrm{CuO}$ (table 1 ). This is present as minute copper particles, typically less than $1 \mu \mathrm{m}$ in diameter, dispersed throughout the glass matrix. ${ }^{9,17}$ These particles could just be resolved in the SEM, but are not easily seen in the backscattered electron micrographs. However, they appear brighter around the slag inclusions due to their larger sizes in these regions (figs. 1, 2 and 5). The visible particles are too large to contribute to the red colouration. The colour is instead produced by much smaller copper nanoparticles which are below the resolution of the SEM; TEM using higher magnifications is needed to resolve them. ${ }^{9,17}$ The lead content is variable between samples (table 1), but the majority typically contain less than $20 \% \mathrm{PbO}$ and can therefore be classed as low lead - low copper reds, although a small number have an intermediate composition with higher PbO levels (up to $30 \%$ ).

All of the glasses have very high iron contents, typically containing approximately $2-6 \% \mathrm{Fe}_{2} \mathrm{O}_{3}$ (table 1 ). The manganese contents of the glasses are also variable, $\mathrm{MnO}$ being present in quantities of up to $2 \%$. Tin was detected in a number of glasses (up to $2.2 \% \mathrm{SnO}_{2}$ ), with sparse tin oxide crystals visible in several samples. However, lead-tin oxide particles were more frequently encountered (figs. 1 and 2), as is typically seen as both a colourant and opacifying agent (lead stannate, $\mathrm{PbSnO}_{3}$ ) in opaque yellow glass produced during the first millennium AD. ${ }^{23,24}$ Zinc was also detected in some of the glasses. Whilst the majority contain low levels of $\mathrm{ZnO}$ (less than $0.2 \%$ ), a few contain $0.5-1.1 \%$. However, zinc was not detected in any of the 'black' glasses analysed, slag-bearing or otherwise. As the 'black' glasses also contain no 
copper, we may assume that $\mathrm{Zn}$ was added incidentally with $\mathrm{Cu}$, probably as scale or dross from oxidised zinc-bearing copper alloy (brass or gunmetal).

Table 2. EDS area analyses of selected kirschsteinitic and fayalitic slag inclusions in the opaque red and 'black' glasses.

\begin{tabular}{|c|c|c|c|c|c|c|c|c|c|c|c|c|c|c|}
\hline \multirow[t]{2}{*}{ Sample $^{\mathrm{a}}$} & \multicolumn{14}{|c|}{ Oxide $(w t \%)^{b}$} \\
\hline & $\mathrm{Na}_{2} \mathrm{O}$ & MgO & $\mathbf{A l}_{2} \mathbf{O}_{3}$ & $\mathrm{SiO}_{2}$ & $\mathbf{P}_{2} \mathbf{O}_{5}$ & $\mathrm{SO}_{3}$ & $\mathrm{~K}_{2} \mathrm{O}$ & $\mathrm{CaO}$ & $\mathrm{TiO}_{2}$ & MnO & $\mathrm{Fe}_{2} \mathrm{O}_{3}$ & FeO & $\mathrm{CuO}$ & PbO \\
\hline \multicolumn{15}{|c|}{ Fayalitic slag } \\
\hline Fayalite & - & - & - & 29.5 & - & - & - & - & - & - & - & 70.5 & - & - \\
\hline ERL046:G43:1721 & 6.7 & 0.2 & 2.5 & 22.3 & 1.0 & b.d. & 0.3 & 1.2 & b.d. & 1.1 & 62.2 & $(56.0)$ & b.d. & 1.9 \\
\hline ERL104:G107:1141 & 6.7 & 0.3 & 3.6 & 17.0 & 0.6 & b.d. & 0.6 & 1.2 & 0.2 & 1.0 & 65.5 & $(58.9)$ & 0.7 & 1.9 \\
\hline ERL104:G148:2739 & 4.0 & 0.2 & 1.6 & 28.8 & 3.1 & 0.3 & 0.3 & 5.2 & 0.2 & 0.4 & 55.3 & $(49.8)$ & b.d. & b.d. \\
\hline ERL104:G242:2203 & 3.4 & 0.3 & 3.2 & 20.9 & 1.5 & b.d. & 1.1 & 2.5 & b.d. & 0.2 & 65.7 & $(59.1)$ & b.d. & b.d. \\
\hline ERL104:G242:2282 & 2.1 & 1.5 & 0.1 & 27.2 & 0.7 & b.d. & b.d. & 1.0 & b.d. & 0.4 & 65.8 & $(59.2)$ & b.d. & 0.6 \\
\hline ERL104:G268:3257 & 0.9 & 0.3 & 2.4 & 22.5 & 1.4 & b.d. & 0.3 & 4.8 & b.d. & 0.1 & 67.0 & $(60.3)$ & b.d. & b.d. \\
\hline ERL104:G242:2273/16 & 7.4 & 0.4 & 4.8 & 19.6 & 0.8 & b.d. & 0.3 & 1.5 & 0.2 & 1.1 & 57.5 & $(51.7)$ & b.d. & 4.5 \\
\hline \multicolumn{15}{|c|}{ Kirschsteinitic slag } \\
\hline Kirschsteinite & - & - & - & 32.0 & - & - & - & 29.8 & - & - & - & 38.2 & - & \\
\hline ERL104:G281:1795 & 1.0 & 1.5 & 5.3 & 27.2 & 2.0 & b.d. & 0.6 & 21.5 & 0.3 & 0.6 & 39.5 & (35.6) & b.d. & b.d. \\
\hline ERL104:G268:3260 & 1.9 & 0.5 & 2.4 & 30.0 & 2.5 & 0.4 & 0.3 & 24.3 & 0.2 & 0.5 & 36.5 & $(32.8)$ & b.d. & b.d. \\
\hline ERL104:G268:3260 & 0.7 & 0.8 & 0.9 & 28.0 & 2.2 & 0.2 & b.d. & 25.0 & 0.1 & 0.7 & 40.9 & $(36.8)$ & b.d. & b.d. \\
\hline
\end{tabular}

${ }^{a}$ Repeated samples represent analyses of different areas of the same sample. ERL104:G242:2273/16 is a 'black' glass. Theoretical compositions in italics: fayalite $\left(\mathrm{Fe}_{2} \mathrm{SiO}_{4}\right)$ and kirschsteinite $\left(\mathrm{CaFeSiO}_{4}\right)$.

${ }^{\mathrm{b}}$ Area analyses normalised to 100 percent; see text for details. b.d. = below detection. For detection limits see table 1. $\mathrm{FeO}$ content calculated from $\mathrm{Fe}_{2} \mathrm{O}_{3}$. Chlorine $(\mathrm{Cl})$ and the oxides of cobalt $(\mathrm{CoO})$ nickel $(\mathrm{NiO})$, zinc $(\mathrm{ZnO})$, arsenic $\left(\mathrm{As}_{2} \mathrm{O}_{3}\right)$, tin $\left(\mathrm{SnO}_{2}\right)$, antimony $\left(\mathrm{Sb}_{2} \mathrm{O}_{5}\right)$ and barium $(\mathrm{BaO})$ were analysed for but not detected.

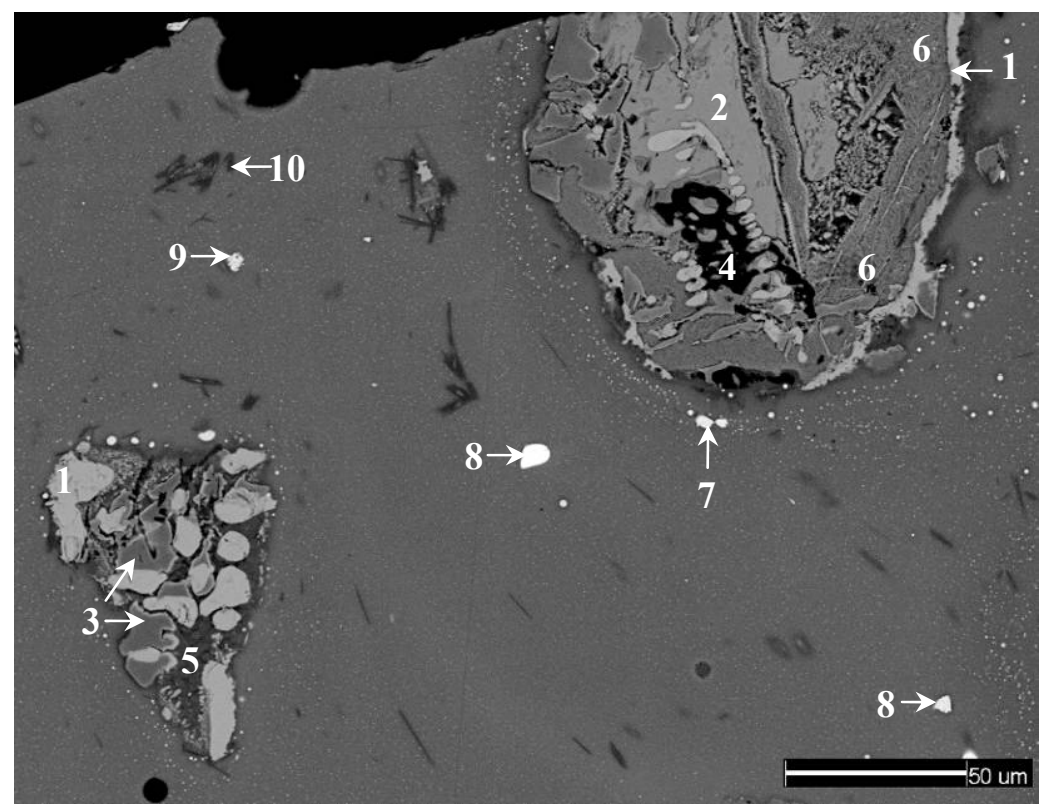

Figure 1. Backscattered electron micrograph of bead ERL104:G242:2158, showing fayalitic slag inclusions in an opaque red glass matrix coloured by copper nanoparticles. The slag primarily consists of irregular grains of wüstite (1), together with fayalite (2), hercynite (3), leucite (4) and interstitial glass (5). The 'feathery' phases (6) correspond to fayalite with elevated soda and lime. Metallic copper particles are visible surrounding the slag (7), together with sparse lead-tin oxide (8) and tin oxide (9) crystals, and dark crystals of wollastonite (10). 
Table 3. Selected EDS spot analyses of phases within kirschsteinitic and fayalitic slag inclusions.

\begin{tabular}{|c|c|c|c|c|c|c|c|c|c|c|c|c|c|c|c|}
\hline \multirow[t]{2}{*}{ Sample $^{\mathrm{a}}$} & \multicolumn{15}{|c|}{ Oxide (wt\%) $)^{\mathrm{b}}$} \\
\hline & $\mathrm{Na}_{2} \mathrm{O}$ & MgO & $\mathbf{A l}_{2} \mathbf{O}_{3}$ & $\mathrm{SiO}_{2}$ & $\mathbf{P}_{2} \mathbf{O}_{5}$ & $\mathrm{SO}_{3}$ & $\mathbf{K}_{2} \mathbf{O}$ & $\mathrm{CaO}$ & $\mathrm{TiO}_{2}$ & MnO & $\mathrm{Fe}_{2} \mathrm{O}_{3}$ & $\mathrm{FeO}$ & $\mathrm{CuO}$ & $\mathrm{BaO}$ & $\mathrm{PbO}$ \\
\hline \multicolumn{16}{|c|}{ Fayalitic slag } \\
\hline Fayalite & - & - & - & 29.5 & - & - & - & - & - & - & - & 70.5 & - & - & - \\
\hline ERL046:G03:1271 & b.d. & 0.5 & 0.3 & 26.8 & 0.3 & b.d. & b.d. & b.d. & b.d. & 2.0 & 69.8 & $(62.8)$ & b.d. & b.d. & b.d. \\
\hline ERL046:G38:1046 & b.d. & 0.3 & b.d. & 27.2 & 0.2 & b.d. & b.d. & 0.8 & b.d. & 0.1 & 71.0 & (63.9) & b.d. & b.d. & b.d. \\
\hline ERL104:G268:3258 & b.d. & 0.7 & 0.3 & 26.0 & 0.3 & b.d. & b.d. & 0.2 & b.d. & b.d. & 71.7 & $(64.5)$ & b.d. & b.d. & b.d. \\
\hline Leucite & - & - & 23.4 & 55.1 & - & - & 21.6 & - & - & - & - & - & - & - & - \\
\hline ERL046:G03:1303 & 5.1 & b.d & 24.3 & 56.1 & 0.1 & 0.1 & 13.2 & b.d. & b.d. & b.d. & 0.3 & - & b.d. & 0.2 & b.d. \\
\hline ERL046:G43:1721 & 4.4 & b.d & 18.9 & 63.6 & 0.2 & 0.2 & 10.9 & b.d. & 0.1 & b.d. & 0.2 & - & b.d. & 1.0 & b.d. \\
\hline ERL104:G242:2196 & 2.8 & b.d. & 23.0 & 53.9 & 0.4 & b.d. & 15.8 & 0.3 & b.d. & b.d. & 3.0 & - & b.d. & b.d. & b.d. \\
\hline Hercynite & - & - & 58.7 & - & - & - & - & - & - & - & - & 41.3 & - & - & - \\
\hline ERL046:G03:1271 & b.d. & b.d. & 42.7 & 0.8 & b.d. & b.d. & b.d. & b.d. & 0.7 & 0.5 & 54.6 & $(49.1)$ & b.d. & b.d. & b.d. \\
\hline ERL104:G148:2743 & b.d. & 0.1 & 47.6 & 0.6 & b.d. & b.d. & b.d. & b.d. & 0.4 & 0.7 & 49.6 & (44.7) & b.d. & b.d. & b.d. \\
\hline ERL104:G305:1820 & b.d. & 0.1 & 42.6 & 0.8 & 0.2 & b.d. & b.d. & b.d. & 0.9 & 0.6 & 54.5 & $(49.0)$ & b.d. & b.d. & b.d. \\
\hline \multicolumn{16}{|l|}{ Interstitial glass } \\
\hline ERL046:G03:1271 & 16.2 & 0.1 & 18.6 & 31.8 & 13.0 & 0.4 & 0.4 & 1.1 & 0.1 & 0.7 & 16.4 & - & 0.6 & 0.2 & b.d. \\
\hline ERL104:G242:2158 & 12.3 & b.d. & 5.2 & 47.5 & 1.2 & 0.3 & 0.6 & 3.9 & 0.1 & 0.3 & 23.3 & - & 0.8 & b.d. & 3.2 \\
\hline ERL104:G242:2158 & 1.1 & 0.1 & 0.6 & 70.1 & 0.1 & 0.1 & 0.2 & 0.9 & b.d. & 0.1 & 26.0 & - & b.d. & b.d. & b.d. \\
\hline ERL104:G242:2207 & 8.8 & b.d. & 17.9 & 40.9 & 6.7 & 0.3 & 1.3 & 4.1 & 1.2 & 0.5 & 15.3 & - & 2.4 & b.d. & 0.5 \\
\hline ERL104:G242:2207 & 7.4 & b.d. & 17.8 & 39.3 & 6.2 & 0.4 & 1.2 & 7.7 & 1.1 & 0.8 & 18.7 & - & b.d. & b.d. & b.d. \\
\hline ERL104:G268:3256 & 14.6 & 0.1 & 18.4 & 31.2 & 8.3 & 1.2 & 0.3 & 6.0 & 0.4 & 0.2 & 17.3 & - & 2.2 & b.d. & b.d. \\
\hline ERL104:G362:1961 & 8.9 & 0.4 & 1.2 & 39.7 & 1.7 & b.d. & b.d. & 4.1 & 0.1 & 0.5 & 38.0 & - & 1.6 & b.d. & 3.3 \\
\hline \multicolumn{16}{|c|}{ Kirschsteinitic slag } \\
\hline Kirschsteinite & - & - & - & 32.0 & - & - & - & 29.8 & - & - & - & 38.2 & - & - & - \\
\hline ERL104:G268:3260 & 0.1 & 0.8 & 0.3 & 29.5 & 1.9 & 0.1 & b.d. & 30.0 & b.d. & 0.7 & 37.5 & $(33.7)$ & b.d. & b.d. & b.d. \\
\hline ERL104:G281:1795 & 0.2 & 3.0 & 0.2 & 29.9 & 1.9 & b.d. & b.d. & 28.5 & b.d. & 0.7 & 35.1 & $(31.6)$ & b.d. & b.d. & b.d. \\
\hline \multicolumn{16}{|l|}{ Interstitial glass } \\
\hline ERL104:G268:3260 & 6.2 & 0.2 & 5.8 & 38.1 & 4.2 & 1.2 & 0.3 & 26.0 & 0.3 & 0.4 & 13.9 & - & 2.7 & 0.2 & 0.6 \\
\hline ERL104:G268:3260 & 6.9 & 0.1 & 5.8 & 30.5 & 11.1 & 1.0 & 0.5 & 18.8 & 0.1 & 0.4 & 20.3 & - & 2.1 & 0.5 & 1.5 \\
\hline ERL104:G281:1795 & 4.0 & 0.4 & 12.9 & 37.3 & 2.4 & 0.2 & 2.0 & 14.2 & 0.6 & 0.3 & 25.2 & - & b.d. & b.d. & b.d. \\
\hline ERL104:G281:1795 & 0.4 & 0.6 & 21.5 & 25.4 & 3.6 & 0.2 & 1.6 & 19.5 & 0.9 & 0.4 & 25.8 & - & b.d. & 0.2 & b.d. \\
\hline
\end{tabular}

${ }^{a}$ Repeated samples represent analyses of different areas of the same sample. Theoretical compositions in italics: fayalite $\left(\mathrm{Fe}_{2} \mathrm{SiO}_{4}\right)$, leucite $\left(\mathrm{KAlSi}_{2} \mathrm{O}_{6}\right)$, hercynite $\left(\mathrm{FeAl}_{2} \mathrm{O}_{4}\right)$ and kirschsteinite $\left(\mathrm{CaFeSiO}_{4}\right)$.

${ }^{\mathrm{b}} \mathrm{Spot}$ analyses normalised to 100 percent; see text and notes to tables 1 and 2 for details.

Table 4. EDS spot analyses of selected nepheline inclusions within some opaque red glasses.

\begin{tabular}{|c|c|c|c|c|c|c|c|c|}
\hline \multirow[t]{2}{*}{ Sample } & \multicolumn{8}{|c|}{ Oxide (wt\%) ${ }^{\mathrm{a}}$} \\
\hline & $\mathrm{Na}_{2} \mathrm{O}$ & $\mathbf{A l}_{2} \mathbf{O}_{3}$ & $\mathrm{SiO}_{2}$ & $\mathrm{~K}_{2} \mathrm{O}$ & $\mathrm{CaO}$ & $\mathrm{Fe}_{2} \mathrm{O}_{3}$ & $\mathrm{SnO}_{2}$ & PbO \\
\hline Nepheline ${ }^{\mathrm{b}}$ & 15.9 & 34.9 & 41.1 & 8.1 & - & - & - & - \\
\hline ERL104:G242:2145 & 17.8 & 33.9 & 42.7 & 1.8 & 0.8 & 0.9 & 0.4 & 0.8 \\
\hline ERL104:G263:1406 & 17.8 & 34.1 & 43.5 & 1.6 & 0.7 & 0.4 & b.d. & 1.0 \\
\hline ERL104:G268:3260 & 18.6 & 33.6 & 41.5 & 1.9 & 0.6 & 1.4 & b.d. & 1.2 \\
\hline
\end{tabular}

${ }^{a}$ Spot analyses normalised to 100 percent; see text and notes to tables 1 and 2 for details. b.d. = below detection.

${ }^{\mathrm{b}}$ Theoretical composition of nepheline $\left(\mathrm{Na}_{3} \mathrm{KAl}_{4} \mathrm{Si}_{4} \mathrm{O}_{16}\right)$. 


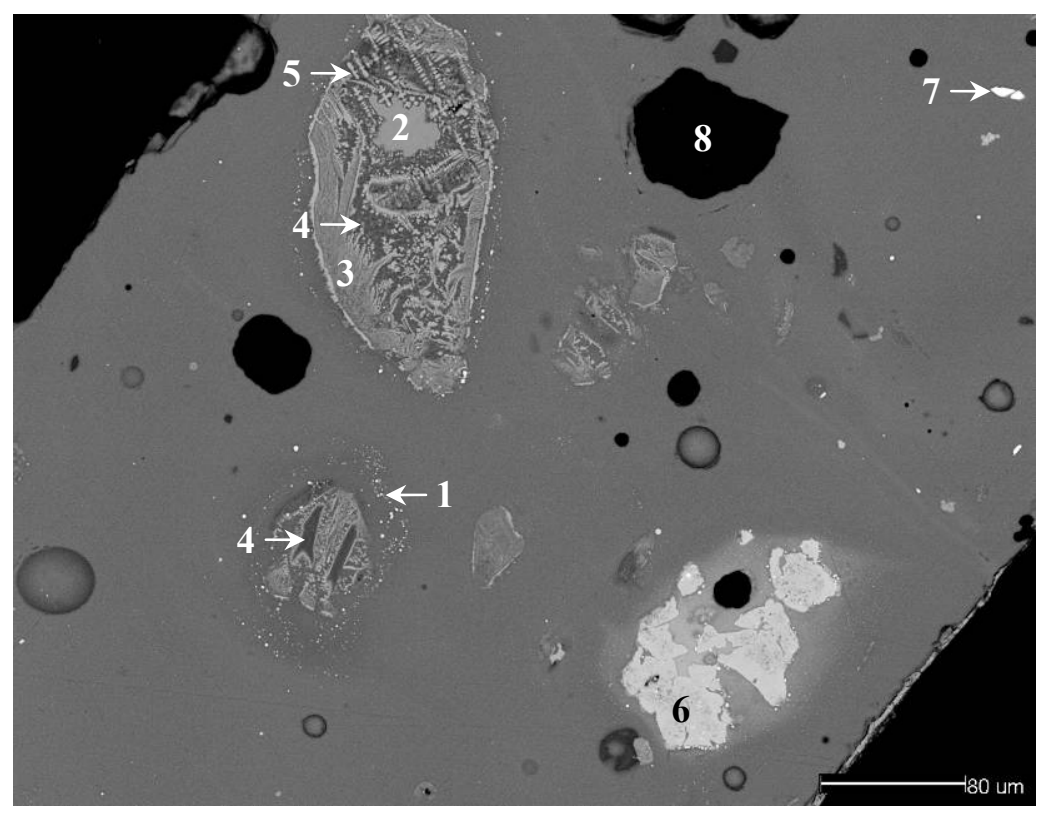

Figure 2. Backscattered electron micrograph of bead ERL104:G242:2207, showing inclusions of fayalitic slag in an opaque red glass matrix coloured by copper nanoparticles. Metallic copper particles (1) can be seen surrounding these inclusions. The slag particles primarily consist of solid phases of fayalite (2) and fayalitic intergrowths (3), interstitial glass (4) and iron oxide dendrites (5). An angular inclusion rich in iron and copper (6), and sparse leadtin oxide crystals are also visible (7). The black areas (8) represent voids.

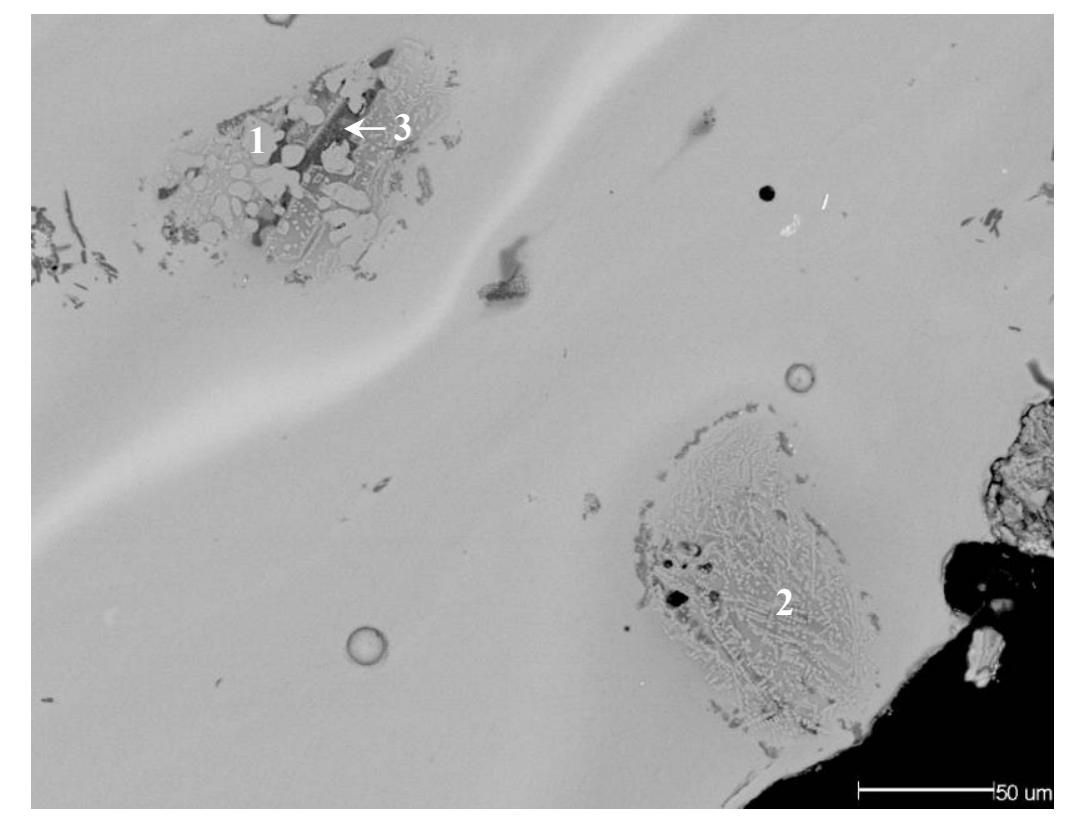

Figure 3. Backscattered electron micrograph of bead ERL104:G242:2273/16, showing inclusions of fayalitic slag in a high-lead 'black' glass matrix coloured by iron. The slag particles consist of irregular wüstite grains (1), together with intergrowths of fayalite (2) and interstitial silicate glass (3). The slag has clearly begun to dissolve in the surrounding glass matrix. Note the absence of copper particles surrounding the slag, in contrast to figs. 1 and 2.

It is the microstructure of the red glasses that is of interest here. They are all very heterogeneous, and in many cases contain a number of large bubbles (e.g. fig. 4), demonstrating that a considerable amount of gas was released when the 
glass was molten, and that melting times were relatively short or temperatures low. Angular particles of slag are distributed throughout the glass matrix, typically ranging in size from $10-200 \mu \mathrm{m}$, but in some cases up to $400 \mu \mathrm{m}$ across. These inclusions are complex and very variable, but are mostly of the same type. They are all iron silicate slags (table 2), primarily consisting of varying amounts of olivine and iron oxide, together with interstitial glassy phases (table 3 ).

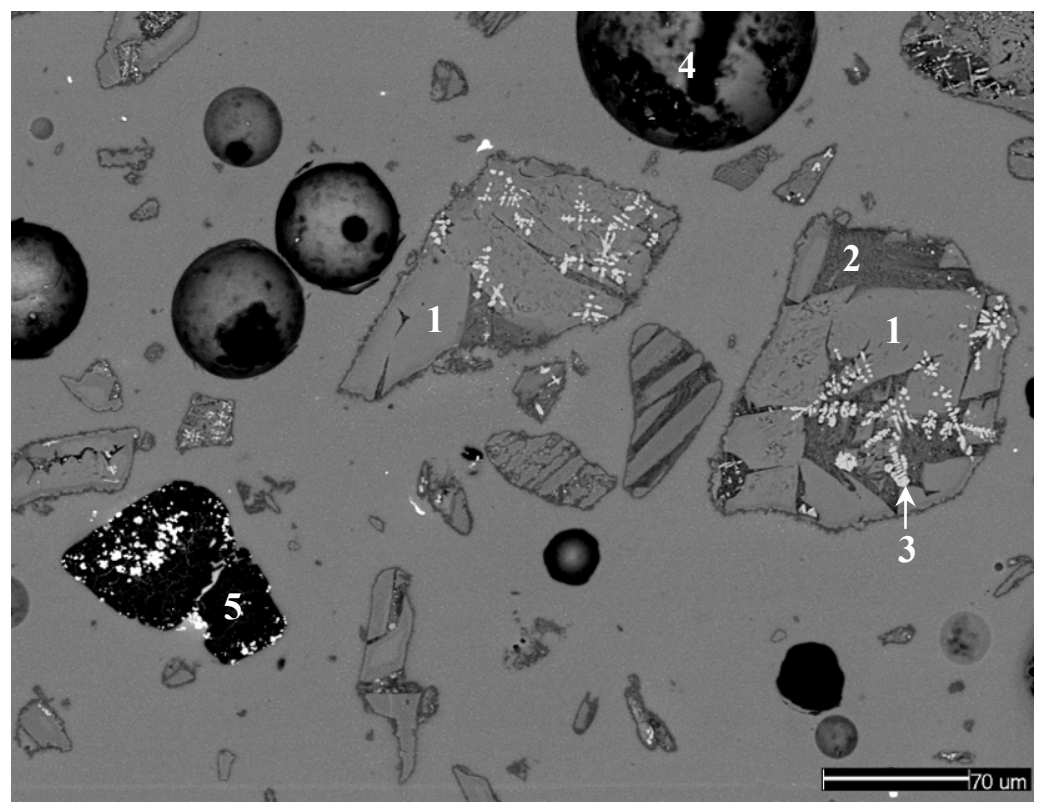

Figure 4. Backscattered electron micrograph of bead ERL104:G268:3260, showing a high density of kirschsteinitic slag inclusions in an opaque red glass matrix coloured by copper nanoparticles. The main phase of the slag corresponds to kirschsteinite (1). Also present are interstitial glassy phases (2) and dendritic crystals of magnetite (3). A number of bubbles (4) are also visible, and a large nepheline inclusion (5) containing bright lead-tin oxide crystals.

The main phase of the majority of slag inclusions corresponds to the mineral fayalite $\left(\mathrm{Fe}_{2} \mathrm{SiO}_{4}\right)$. Spot analysis of individual phases confirmed its presence (table 3), and area analysis shows a primarily fayalitic composition (table 2). Most are characterised by fine feathery intergrowths of calcic-fayalite in a groundmass of glass (fig. 2), compositionally falling between fayalite and kirschsteinite $\left(\mathrm{CaFeSiO}_{4}\right){ }^{25} \mathrm{In}$ addition to fayalite, wüstite $(\mathrm{FeO})$ was identified as a primary constituent of these slags, forming as large irregular grains or coarse dendrites (fig. 1). A number of minor phases were identified in some of the inclusions (table 3$)$. These were mostly aluminous, corresponding to either hercynite $\left(\mathrm{FeAl}_{2} \mathrm{O}_{4}\right)$, or leucite $\left(\mathrm{KAlSi}_{2} \mathrm{O}_{6}\right.$ ) (table 3 and fig. 1). The vast majority also contain very complex silicate glass phases (figs. 1 and 2), typically consisting of the oxides of iron and silicon, together with variable amounts of soda, phosphate, lime and alumina. However, their composition is inconsistent, even within the same slag inclusion (table 3 ).

The complex and fine-grained microstructure of the slag inclusions can constrain the determination of the composition of the interstitial glassy phases. Whilst $\mathrm{CuO}$ was generally not present in any significant quantity in the majority of these phases, some were found to contain high levels. In two beads (table 3, samples ERL104:G268:3256 and ERL104:G362:1961), the CuO levels detected in the interstitial glass notably exceeds that colouring the surrounding glass matrix (table 1), but in many cases copper is not consistently present in the same slag particle (table 3 , sample ERL104:G242:2207). Furthermore, bulk analysis of the slag shows that copper is not present in significant quantities (table 2). However, in sample ERL104:G242:2207 a large copper-rich inclusion was observed (fig. 2), consisting of $43.3 \%$ metallic copper and $50.2 \%$ iron oxide, together with minor amounts of alumina and tin oxide.

Magnesia and potash are not present in any significant quantity (table 2), with the exception of a small number of potassium-rich phases corresponding to leucite $\left(\mathrm{KAlSi}_{2} \mathrm{O}_{6}\right)$ (table 3). The high soda levels present are unusual, and are not typically seen in the interstitial glassy phases of fayalitic slag. This may reflect some contamination from the 
surrounding soda-lime-silica glass. The high $\mathrm{PbO}$ content in the bulk analyses of some of these slag inclusions (e.g. table 2, samples ERL046:G43:1721 and ERL104:G107:1141) is also likely to have been derived from the surrounding glass.

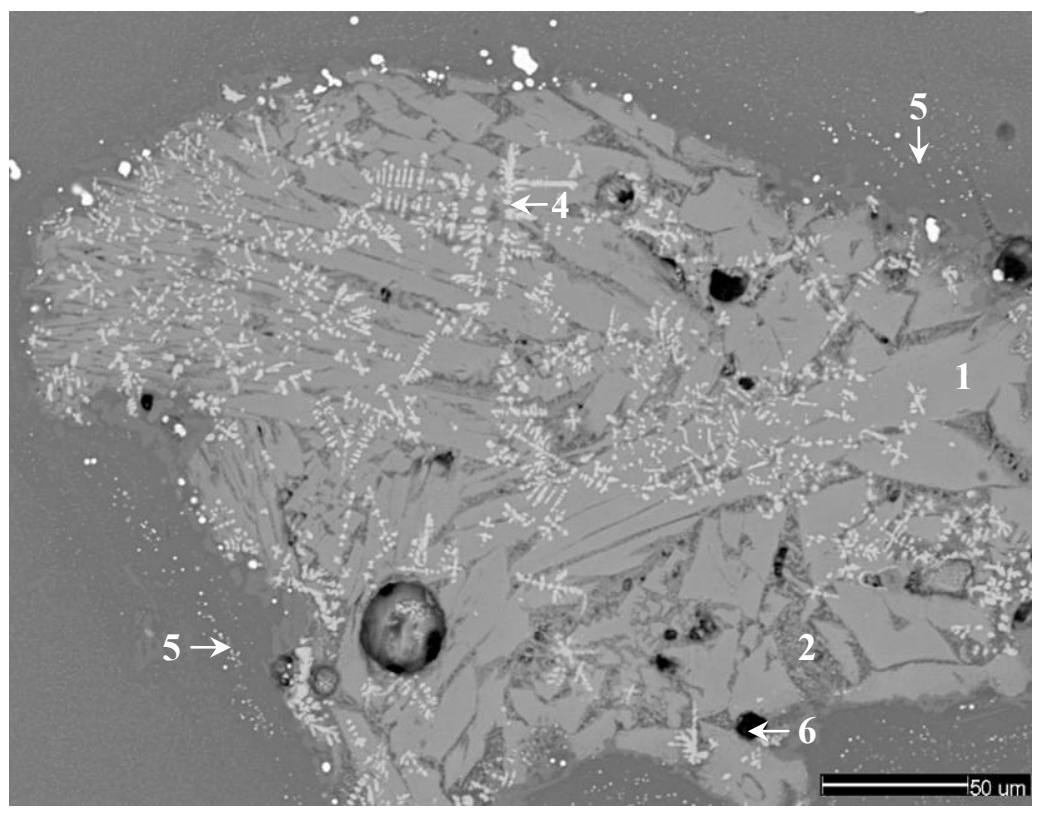

Figure 5. Backscattered electron micrograph of bead ERL104:G281:1795, showing a large kirschsteinitic slag inclusion. The main phase of this slag corresponds to kirschsteinite (1). Interstitial glass is also visible (2), and a number of dendritic magnetite crystals (3), together with zones of bright white copper particles surrounding the inclusion (5). The black areas (6) represent voids.

Similar fayalitic slag inclusions were identified in a small high-lead 'black' glass bead (fig. 3) coloured by high levels of iron (table 1, sample ERL104:G242:2273/16). Here the slag has begun to dissolve, making it difficult to resolve in the SEM, and there is considerable contamination by lead oxide and soda from the surrounding glass (table 2, sample ERL104:G242:2273/16). There are a number of very close similarities in composition and microstructure of this slag to the fayalitic slag identified in the red glasses, suggesting that it was originally of the same type. Of note is the absence of any copper and tin oxide particles in their immediate vicinity (fig. 3), as is characteristic of the red glasses (figs. 1 and 2). Furthermore, the bulk composition of this glass (table 1, sample ERL104:G242:2273/16) shows that copper is absent.

Two of the opaque red glass beads analysed (table 1, samples ERL104:G281:1795 and ERL104:G268:3260) are unusual in that they contain slag in which fayalite is absent; the main phase instead corresponds to kirschsteinite $\left(\mathrm{CaFeSiO}_{4}\right)$, an orthosilicate (olivine-type) mineral characterised by high amounts of the oxides of silicon, iron and calcium (tables 2 and 3). Fine dendritic crystals of magnetite $\left(\mathrm{Fe}_{3} \mathrm{O}_{4}\right)$ (identified by spot analysis) are clearly visible in these inclusions (figs. 4 and 5), in contrast to the irregular grains and coarse dendrites of wüstite $(\mathrm{FeO})$ typically present in the fayalitic slags (figs. 1 and 3). It is notable that the concentration of slag particles in sample ERL104:G268:3260 (fig. 4) is far greater than that seen in sample ERL104:G281:1795 (fig. 5), or in any of the glasses containing fayalitic slag (figs. 1-3). The interstitial glassy phases of this slag type are quite similar to those seen in the fayalitic variety, but differ in that they contain much more calcium (table 3), due to the calcic nature of the other phases present. Of particular interest is the detection of copper in the interstitial glass in the slag in sample ERL104:G268:3260 (table 3). Here up to approximately $2.5 \% \mathrm{CuO}$ was detected; considerably more than the $0.9 \%$ which colours the glass (table 1 ).

Many of the red glasses (those containing both kirschsteinitic and fayalitic slag) contain sporadic sodium aluminium silicate inclusions, ranging in size from $10-100 \mu \mathrm{m}$ across, corresponding to the mineral nepheline $\left(\mathrm{Na}_{3} \mathrm{KAl}_{4} \mathrm{Si}_{4} \mathrm{O}_{16}\right)$ or its artificial form carnegieite $\left(\mathrm{NaAlSiO}_{4}\right)$ in which potassium is absent (table 4), and usually associated with numerous crystals of lead-tin oxide (fig. 4). A number of samples also contain calcium-rich devitrification products, corresponding to wollastonite $\left(\mathrm{CaSiO}_{3}\right)$, typically seen as acicular crystals in the glass matrix (fig. 1). 


\section{DISCUSSION}

The opaque copper-red glasses under investigation consistently contain angular particles of crushed metallurgical slag. Iron-rich slags of the fayalitic variety were typical of both copper- and iron-smelting technologies throughout the ancient and medieval worlds, ${ }^{26-29}$ due to the powerful effect of iron as a flux. ${ }^{29}$ Fayalitic slag may also occur as a by-product of iron smithing. ${ }^{26,30}$ Kirschsteinite may occur in both iron- and copper-smelting slags, ${ }^{25,26,28}$ but is less likely in ironsmithing slag, which is produced as a reaction between the iron scale on the artefact being worked and a quartz sand flux. ${ }^{30}$ Kirschsteinite in iron-smelting slag typically occurs as calcium-rich rims on fayalite cores, rather than as a homogeneous phase as observed here. ${ }^{31}$ Furthermore, the presence of magnetite $\left(\mathrm{Fe}_{3} \mathrm{O}_{4}\right)$ in the kirschsteinitic slags suggests that conditions were too oxidising to reduce iron to metal; wüstite $(\mathrm{FeO})$ would be the stable iron oxide phase under such conditions. ${ }^{29}$ On balance therefore, it would appear that the kirschsteinitic slags are likely to be coppersmelting slag. This interpretation is borne out by the occurrence of copper at around two percent in the interstitial glass in slag from sample ERL104:G268:3260. It is possible that the slag fragments are contaminated by copper from the glass; however, the zones of metallic copper precipitation around the slag particles indicate that conditions in the slag would have inhibited diffusion of copper by reducing it to metal.

What is less clear is whether the fayalitic slags were formed as the result of iron or copper production. High copper concentrations are detected in a significant proportion of the interstitial glasses of the fayalitic slags (table 3), but the interstitial glass also frequently contains high sodium which is likely to have been derived from the soda-lime-silica glass of the beads. The fayalitic slags are clearly more reducing than the kirschsteinitic types, as they contain wüstite rather than magnetite. ${ }^{27}$ Their higher iron contents (c. $60 \%$ as opposed to $40 \%$ ) are also more typical of iron-smelting, but could conceivably represent copper-smelting slag. ${ }^{26,28,29}$ Smelting copper under such highly reducing conditions is likely to lead to the precipitation of iron-copper alloy, ${ }^{32}$ and while it is just possible that the large iron oxide - copper metal inclusion in sample ERL104:G242:2207 (fig. 2) represents such an alloy phase, it is unfortunate that this inclusion is not directly associated with the slag. On balance it seems more likely that the fayalitic slag resulted from iron-smelting.

The detection of compositionally similar fayalitic slag additions in a high-lead 'black' glass bead supports this view. This glass contains no detectable copper (table 1, sample ERL104:G242:2273/16) and there are no copper particles surrounding the slag inclusions (fig. 3), as is commonly seen in the red glasses (figs. 1 and 2). It has been suggested that 'black' glasses may have been produced by mixing together coloured scrap glass of different colours, ${ }^{33}$ but the absence of copper indicates that scrap red glass is unlikely to have been used here. Furthermore, this suggests that copper was added to the glasses separately from the slag, supporting the view that the fayalitic slags are derived from iron-smelting.

The differences between the fayalitic and kirschsteinitic slags are in both elemental composition (high versus low $\mathrm{CaO}$ and $\mathrm{FeO}$, table 2) and in redox state. Irrespective of whether they reflect the smelting of different metals, they are unlikely to represent the by-products of a single process at a single place and time. At least two different slag sources appear to have been exploited by the glass workers. This may be related to the period in which the two glass types were produced, it may reflect the production of red glass in two (or more) different workshops, or it may reflect the availability of different slag types to a single glass workshop. It seems unlikely that the beads were produced at different times; beads ERL104:G268:3260 (kirschsteinitic), ERL104:G268:3257 and ERL104:G268:3258 (both fayalitic) are all from the same grave, although the possibility of inheritance or importation of beads from different workshops cannot be eliminated. It seems more plausible that these beads were produced in different workshops, which are likely to have been located in close proximity to the copper- and iron-smelting industries respectively. Alternatively they might reflect the exploitation by a single glass workshop of different contexts of a historic metallurgical slag deposit, where smelting processes differed at different periods. It is observed that the two glasses containing the kirschsteinitic slag inclusions cannot be differentiated from those containing fayalitic slag inclusions based on the bulk composition of the glass alone (table 1), emphasising the importance of invasive analysis in their characterisation.

The concentrations of relatively large copper particles around the slag inclusions indicate that the slag additions served the function of reducing the copper in the glass to the metallic state, thus generating the red colouration, as has been suggested by Heck and Hoffmann ${ }^{34}$ for an occurrence of slag in a Merovingian glass bead. However, as previously stated, the red colour is produced by copper nanoparticles which are too small to be resolved in the SEM; ${ }^{9,17}$ the copper particles visible in the backscattered electron micrographs (e.g. figs. 1,2 and 5) are too large to contribute to the colour. The presence of copper in the kirschsteinitic slags along with their apparent derivation from copper-smelting also raises the possibility that the slag may itself have served as a source of copper in some cases; however, the bulk copper 
contents of the slags are very low (table 2), well below those of the glass, so this is unlikely. Furthermore, the slag particles would have had to dissolve in the glass, and while it is clear that some interaction has occurred, they appear to have largely retained their angularity resulting from the crushing process. Assuming that the iron contents of the glasses originated from the slag, and that the average iron oxide content of slag is $50 \%$ and of glass is $5 \%$, it is estimated that the glass typically contains about $10 \%$ dissolved slag. In order for the slag to have yielded a typical concentration of $2 \%$ $\mathrm{CuO}$ in the glass, it would have had to contain $20 \%$ copper. This is clearly not the case. The solution of $10 \%$ slag is unlikely to have perturbed most of the elemental concentrations in the original soda-lime-silica glass significantly, given our margins of error, except the $\mathrm{P}_{2} \mathrm{O}_{5}$, which has been elevated to higher levels than are normally encountered in natrontype glass (c. $0.3 \%$ as opposed $0.1 \%)$.

In addition to the slag inclusions, particles of $\mathrm{SnO}_{2}$ and $\mathrm{PbSnO}_{3}$ (lead stannate) are also present in many of the glasses. $\mathrm{PbSnO}_{3}$ is an opaque yellow glass colourant which is unstable at if heated for prolonged periods at high temperatures. ${ }^{5}$ Its presence indicates that it was produced as a pre-existing pigment, ${ }^{23,35}$ and suggests that the lead and tin oxides were added to the red glass together. Furthermore, along with the high concentrations of bubbles and the relative angularity of the slag particles, the lead-tin yellow suggests that the red glasses were heated at low temperatures for short periods. The $\mathrm{PbO}: \mathrm{SnO}_{2}$ ratios of the glasses are broadly consistent with or significantly higher than early medieval opaque yellow glasses, which typically have $\mathrm{PbO}: \mathrm{SnO}_{2}$ ratios of around $10{ }^{23}$ Bead ERL104:G268:3260 contains a high number of number of nepheline-lead-tin oxide inclusions as well as a high proportion of kirschsteinitic slag inclusions. Nepheline is likely to have formed due to a reaction between the high sodium oxide content of a soda-lime-silica glass and the clayceramic material of a melting pot. The association of nepheline and lead-tin oxide suggests that this material represents the dregs from a crucible used to make lead-tin yellow pigment for the production of opaque yellow glass, in the manner described by Heck et al. ${ }^{35}$ Indeed, similar nepheline inclusions were observed in many of the opaque yellow glasses from Eriswell. ${ }^{23}$ The reasons for the addition of this lead-rich material are not entirely clear, but lead is frequently found in ancient copper-red glasses, and offers a number of potential advantages. ${ }^{11,19}$

The technical difficulties in producing opaque red glass have been widely acknowledged, ${ }^{10,16}$ which has led to speculation that its production was a specialised industry restricted to a few workshops. However, it is possible that the highly reducing nature of the slag additive allowed the production of this colour by less specialised craftsmen in a larger number of workshops. Furthermore, unpublished data indicate that several of the opaque red glasses were produced using the same base glass as opaque yellow glasses employed in their decoration (author's data). This evidence for the production of opaque reds and yellows in the same workshop ties in with the inference above that the lead and tin in the red glasses derive from a by-product of the production of lead-tin yellow.

It would therefore appear that the opaque red glasses were produced by adding copper (probably as oxide scale or dross from zinc-bearing copper alloy heated to high temperatures), a lead-tin yellow by-product, and iron- or copper-smelting slag to a soda-lime-silica glass. There is evidence for the addition of metallurgical slag in the production of opaque red glass in the early medieval period not only from Eriswell, but also from Spong Hill and Bergh Apton in Norfolk, UK (author's data, unpublished), together with previously identified, apparently isolated, examples from Anglo-Saxon Mucking in Essex ${ }^{33}$ and Merovingian Eichstetten in Germany. ${ }^{34}$ It is therefore likely to have been a well-established manufacturing tradition. The high iron levels detected in opaque red Merovingian beads from Europe, corresponding in some cases to as much as $14 \% \mathrm{Fe}_{2} \mathrm{O}_{3}{ }^{36}$, suggest that a similar technology was employed there. The slag ultimately derived from the extraction of metals from their ores, which at present appear to have certainly included iron, and probably also copper. It is therefore likely that the workshop or workshops producing this glass were located close to workshops producing metal from ore.

Elsewhere it has been suggested that slag-like materials may have been added as a source of copper, but not as a reducing agent. ${ }^{19}$ Red glasses rich in iron oxide occur in the Roman period but there are no reports of slag inclusions. Therefore it seems possible that this technology originated in early medieval Europe. If this is the case, significant interaction between glass workers and the suppliers of the slag is implied - clearly two sources of slag were utilised, suggesting some experimentation. Copper-smelting (or its slag) is less common than iron-smelting, and the use of copper slag might suggest that it was sought out in an attempt to improve the quality of the glass through the use of a copperbearing material. The production of tin and lead-tin oxide colourants and opacifiers implies that these glassworkers were able to access fresh supplies of tin and lead metals as required. It has been understood for some time that copper colourants were derived from copper metal rather than ore. The present study indicates that the glassworkers also utilised 
smelting slag. The use of a wide range of products from the metals industry, from the by-products of smelting to the finished metals, suggests that there was significant interaction between specialists in metal extraction and glass working and it is quite possible that innovations in practice, such as the use of slag described here, originated in these interactions.

\section{CONCLUSIONS}

The analysis of a large number of opaque red Anglo-Saxon glass beads from southeast England has demonstrated the addition of an iron-rich metallurgical slag to this glass as part of the colouring process. Whilst individual instances of similar iron-rich slag inclusions in contemporary opaque red glasses are known from elsewhere, the present study demonstrates the systematic use of slag in this way, and strongly suggests the use of both copper- and iron-smelting slags. Furthermore, slag appears to have been used to colour some copper-free 'black' glasses. In addition, we have presented for the first time evidence that the lead oxide which is frequently found in red glass was derived as a byproduct of the production of lead-tin yellow, closely linking red and yellow glass production.

These results suggest a link between the metal and glass industries during the early medieval period. It seems likely that the workshops producing this glass were located near to workshops producing metals, as copper, lead and tin would have been required to make these colours in addition to slag. The craftsmen producing this glass clearly had an empirical understanding of the role of slag in the formation of the colour, and the identification of similar slag inclusions in opaque red glass beads from contemporary sites in England indicates that this is likely to have been a fairly widespread practice. The beads span a comprehensive period from the fifth to seventh centuries AD, suggesting that this was certainly a longstanding practice. As yet it is not possible to determine whether the workshops producing this glass were located in England or on the Continent, or the extent to which these beads were imported. Invasive microanalysis of contemporary opaque red glass beads from Europe and elsewhere in Britain is necessary in order to confirm this. However, in spite of the analysis of a range of opaque red glasses from mosaics in the Byzantine world, such slag inclusions have not been previously encountered, strongly suggesting that this was a technology specific to northwestern Europe.

\section{ACKNOWLEDGEMENTS}

We thank Jo Caruth, Suffolk County Council Archaeological Service, and John Hines, Cardiff University, for making the Eriswell beads available for analysis. Thanks also to the Ministry of Defence for funding the project. Finally, we thank Tim Young for his comments and Phil Parkes, Cardiff University, for the production of the reference standards spectra.

\section{REFERENCES}

[1] Peltenburg, E., "Early faience: recent studies, origins and relations with glass," Early Vitreous Materials, British Museum, London, 5-29 (1987).

[2] Mass, J. L., Stone, R. E. and Wypyski, M. T., "An investigation of the antimony-containing minerals used by the Romans to prepare opaque coloured glasses," Proc. MRS 462, 193-204 (1997).

[3] Mass, J., Stone, R. and Wypyski, M., "The mineralogical and metallurgical origins of Roman opaque coloured glasses," The Prehistory and History of Glassmaking Technology, The American Ceramic Society, Westerville, 121-144 (1998).

[4] Shortland, A. J., "The use and origin of antimonate colorants in early Egyptian glass," Archaeometry 44(4), 517-530 (2002).

[5] Tite, M., Pradell, T. and Shortland, A., "Discovery, production and use of tin-based opacifiers in glasses, enamels and glazes from the Late Iron Age onwards: a reassessment," Archaeometry 50(1), 67-84 (2008).

[6] Rehren, Th., "Comments on J. L. Mass, M. T. Wypyski and R. E. Stone, 'Malkata and Lisht glassmaking technologies: towards a specific link between second millennium BC metallurgists and glassmakers', Archaeometry, 44(1) (2002), 67-82, and reply," Archaeometry 45(1), 185-198 (2003).

[7] Frederickx, P., De Ryck, I., Janssens, K., Schryvers, D., Petit, J.-P. and Döcking, H., "EPMA and $\mu$-SRXRF analysis and TEM-based microstructure characterization of a set of Roman glass fragments," X-Ray Spectrom. 33, 326-333 (2004).

[8] Sayre, E. V. and Smith, R. W., "Some materials of glass manufacturing in antiquity," Archaeological Chemistry: A Symposium, University of Pennsylvania Press, Philadelphia, 279-311 (1967). 
[9] Brun, N., Mazerolles, L. and Pernot, M., "Microstructure of opaque red glass containing copper," J. Mater. Sci. Lett. 10, 1418-1420 (1991).

[10] Brill, R. H. and Cahill, N. D., "A red opaque glass from Sardis and some thoughts on red opaques in general," J. Glass Studies 30, 16-27 (1988).

[11] Freestone, I. C., "Composition and microstructure of early opaque red glass," Early Vitreous Materials, British Museum, London, 173-191 (1987).

[12] Henderson, J., "The raw materials of early glass production," Oxford J. Arch. 4(3), 267-291 (1985).

[13]Davis, M. and Gwilt, A., "Material, style and identity in the first century AD metalwork, with particular reference to the Severn Sisters hoard," Rethinking Celtic Art, Oxbow Books, Oxford, 146-184 (2008).

[14] Stapleton, C. P., Freestone, I. C. and Bowman, S. G. E., "Composition and origin of early mediaeval opaque red enamel from Britain and Ireland," J. Arch. Sci. 26, 913-921 (1999).

[15] Henderson, J., "The scientific analysis of ancient glass and its archaeological interpretation," Scientific Analysis in Archaeology, Oxford University Committee for Archaeology, Oxford, 30-62 (1989).

[16] Hughes, M. J., "A technical study of opaque red glass of the Iron Age in Britain,” Proc. Prehist. Soc. 38, 98-107 (1972).

[17] Barber, D. J., Freestone, I. C. and Moulding, K. M., "Ancient copper red glasses: investigation and analysis by microbeam techniques," From Mine to Microscope: Advances in the Study of Ancient Technology, Oxbow Books, Oxford, 115-127 (2009).

[18] Cable, M. and Smedley, J. W., "The replication of an opaque red glass from Nimrud," Early Vitreous Materials, British Museum, London, 151-164 (1987).

[19] Freestone, I. C., Stapleton, C. P. and Rigby, V., "The production of red glass and enamel in the Late Iron Age, Roman and Byzantine periods," Through a Glass Brightly: Studies in Byzantine and Medieval Art and Archaeology Presented to David Buckton, Oxbow Books, Oxford, 142-154 (2003).

[20] Brugmann, B., [Glass Beads from Early Anglo-Saxon Graves: A Study of the Provenance and Chronology of Glass Beads from Early Anglo-Saxon Graves, Based on Visual Examination], Oxbow Books, Oxford (2004).

[21] Brill, R. H., [Chemical Analyses of Early Glasses], Corning Museum of Glass, New York (1999).

[22] Shortland, A., Schachner, L., Freestone, I. and Tite, M., "Natron as a flux in the early vitreous materials industry: sources, beginnings and reasons for decline," J. Arch. Sci. 33, 521-530 (2006).

[23] Peake, J. R. N. and Freestone, I. C., "Opaque yellow glass production in the early medieval period: new evidence," in press.

[24] Rooksby, H. P., “A yellow cubic lead tin oxide opacifier in ancient glasses,” Phys. Chem. Glasses 5(1), 20-25 (1964).

[25] Sharp, W. E. and Mittwede, S. K., "Medieval kirschsteinite-bearing iron slags of the Develi-Yahyali area (Kayseri), Turkey,” Proc. ICAM 2011, 649-656 (2011).

[26] Bachmann, H.-G., [The Identification of Slags from Archaeological Sites], Institute of Archaeology, London (1982).

[27] Hauptmann, A., [The Archaeometallurgy of Copper: Evidence from Faynan, Jordan], Springer, Berlin (2007).

[28] Manasse, A., Mellini, M. and Viti, C., "The copper slags of the Capatolli Valley, Campiglia Marittima, Italy," Eur. J. Mineral. 13, 949-960 (2001).

[29] Severin, T., Rehren, Th. and Schleicher, H., "Early metal smelting in Aksum, Ethiopia: copper or iron?,” Eur. J. Mineral. 23, 981-992 (2011).

[30] Selskienè, A., "Examination of smelting and smithing slags formed in bloomery iron-making process," Chemija 18(2), 22-28 (2007).

[31] Young, T., Cardiff University, personal communication (2012).

[32] Craddock, P. T. and Meeks, N. D., "Iron in ancient copper," Archaeometry 29(2), 187-204 (1987).

[33] Mortimer, C. and Heyworth, M., "Compositional and structural analysis of glass beads," Excavations at Mucking: Volume 3, The Anglo-Saxon Cemeteries, Museum of London Archaeology, London, 403-413 (2009).

[34]Heck, M. and Hoffmann, P., "Analysis of early medieval glass beads: the raw materials to produce green, orange and brown colours," Mikrochim. Acta 139, 71-76 (2002).

[35] Heck, M., Rehren, Th. and Hoffmann, P., "The production of lead-tin yellow at Merovingian Schleitheim (Switzerland)," Archaeometry 45(1), 33-44 (2003).

[36] Heck, M. and Hoffmann, P., "Coloured opaque glass beads of the Merovingians," Archaeometry 42(2), 341-357 (2000). 